ISSN 1818-1295 elSSN 2616-6194

REPORTS OF MORPHOLOGY
$\begin{gathered}\text { Official Journal of the Scientific Society of Anatomists, } \\ \text { Histologists, Embryologists and Topographic Anatomists } \\ \text { of Ukraine } \\ \text { journal homepage: https://morphology-journal.com }\end{gathered}$

\title{
Morphological evaluation of anal canal wound healing after combined operations for combined anorectal pathology
}

Balytskyy V.V.

Public Non-Profit Enterprise "Khmelnytskyi regional hospital" under Khmelnytskyi Regional Council, Khmelnytskyi, Ukraine

\section{ARTICLE INFO}

Received: 5 August 2021

Accepted: 1 September 2021

UDC: $616.352-089.2-089.168$

\section{CORRESPONDING AUTHOR}

e-mail: v.balytskyy@ukr.net Balytskyy V.V.

\section{CONFLICT OF INTEREST}

The authors have no conflicts of interest to declare.

\section{FUNDING}

Not applicable.

\begin{abstract}
The urgency of the problem of postoperative wound healing after combined operations for combined pathology of the anal canal and rectum is quite high and contributes to the introduction into the practice of coloproctologists of new modern surgical technologies for the treatment of this pathology. The aim of the study was to conduct a comparative morphological assessment of postoperative wound healing in patients with combined pathology of the anal canal and rectum after combined operations using modern highfrequency electrosurgical and radiosurgical technologies. The results of surgical treatment of 689 patients with combined pathology of the anal canal and rectum using high-frequency electrosurgery and radiowave surgery with morphological assessment of wound healing on 3, 5, 7, 14, 21 days of the postoperative period, which were divided into 4 study groups. Using of "Surgitron" and "KLS Martin" devices for the treatment of patients with combined pathology of the anal canal and rectum was accompanied by the formation of the thinnest layers of coagulation necrosis in tissues with a depth of $0.189 \pm 0.085 \mathrm{~mm}$ and $0.194 \pm 0.090 \mathrm{~mm}$ respectively and as result patients of the first and fourth study groups had the shortest duration of inpatient treatment, which was 3-5 days and the average time of wound healing, which was 14-15 days. Patients in these study groups had the lowest inflammatory neutrophil reaction in postoperative wounds on day 3 , which rapidly disappeared by day 5, on days 7-14 they had active reparative processes with the appearance of fibroblasts and connective tissue fibers, and on 21 day squamous epithelial cells, which indicated the processes of active epithelialization of wounds. The effect on the tissues of the devices "EFA" and "ERBE ICC 200" was deeper than in the above groups, forming a layer of coagulation tissue necrosis with a depth of $0.208 \pm 0.097 \mathrm{~mm}$ and $0.302 \pm 0.107 \mathrm{~mm}$ respectively, which was accompanied by patients of the third and second study groups with longer terms of inpatient treatment, which amounted to 5-7 days and increase the duration of wound healing, which amounted to 16-19 days. Patients in the 2nd and 3rd study groups showed a more pronounced inflammatory neutrophilic reaction in postoperative wounds on the 3rd day, which did not disappear until the 5th day and in half of the cases the presence of a significant number of segmental neutrophils and bacterial accumulations persisted. On days 7-14 they had weak reparative processes with the appearance of single fibroblasts and a small number of connective tissue fibers and on the 21st day single squamous epithelial cells, which indicated slow processes of wound epithelization. Using of radio-wave surgery and high-frequency electrosurgery devices promotes active epithelialization of tissues preventing scar strictures of the anal canal and improves the rehabilitation of patients in the postoperative period.

Key words: morphological evaluation, combined anorectal pathology, combined operations, high-frequency electrosurgery devices, radio-wave surgery device, wound healing.
\end{abstract}

\section{Introduction}

The urgency of the problem of combined pathology of the anal canal and rectum is due to the rapidly growing number of proctological diseases, among which the share of combined pathology of the anal canal and rectum is constantly growing, ranging from 35 to $65 \%$ [12]

Over the last two decades, there has been a trend towards a significant increase in combined anorectal pathology, which requires surgical treatment. Thus, in 18- 
$32 \%$ of patients admitted to proctology hospitals, there is a combination of two - three diseases of the anorectal area, which are subject to surgical treatment [2]. The most common combination of hemorrhoids with the following proctological diseases: anal fissure - 12.3-54.3\%, anal fistula - 14.2-40.1\%, anal polyp - 9-18.4\%, anal abscess $9.9 \%$, anal fissure and anal polyp $-4.8 \%$, anal fissure and anal fistula - $1.8 \%$ [2].

The rapid development of the latest surgical technologies has allowed the introduction of new high-tech tools for surgical treatment of various anorectal diseases in coloproctological practice. Thus, Valleylab (USA) has developed a bipolar electrothermal system "Liga Sure" for surgical treatment of hemorrhoids. This method of hemorrhoidectomy is called "closed seamless hemorrhoidectomy" [11]. The depth of thermal impact on the tissues when using this system is $2 \mathrm{~mm}$, which is often accompanied by suppuration of postoperative wounds (2$15 \%$ ) [16], as well as the occurrence of strictures of the anal canal $(2-9 \%)[4,17]$.

The ultrasonic harmonic scalpel "Ultra Cision" from Ethicon Endo-Surgery (USA), whose thermal effect on tissues does not exceed $1.5 \mathrm{~mm}$, has become widely used in coloproctology [10]. But this method, according to some authors, is accompanied by prolonged healing of postoperative wounds of the anal canal $(6 \%)$ and recurrence of anorectal pathology $(9.1 \%)[15,17]$.

Over the last decade, laser technology has become widely used in the treatment of various anorectal pathology. The advantages of these techniques are: low trauma, laser destruction within the submucosal layer, no intra- and postoperative bleeding, short operations, no inflammatory complications and postoperative scars in the area affected by the laser, reducing the duration of treatment of patients [7]. But, at the same time, according to a number of studies, laser techniques have, unfortunately, a number of disadvantages: postoperative edema in the coagulation zone $(6.2-33.1 \%)$, the formation of residual hemorrhoidal skin tags $(14.5 \%)$, long-term healing of anal canal wounds $(5.6 \%)[3,6,13]$.

Prolonged healing of anal canal wounds, which is often accompanied by infection, healing and the occurrence of anal strictures of inflammatory and scar nature has prompted researchers to actively local application a variety of drugs for the treatment of postoperative anal canal wounds. Thus, F. Eshghi and co-authors [5] used aloe vera cream, J.H. Kim and co-authors [8] - sitting baths with ozonated water, U. Rodríguez-Wong and co-authors [14] topical cream diltiazem, A.K. Vejdan et al. [18] - topical sucralfate for the treatment of anal canal wounds after hemorrhoidectomy, which reduced pain and postoperative wound healing time. A.M. Kuz'minov and co-authors [9] used low-temperature argon plasma for the treatment of postoperative wounds in patients after hemorrhoidectomy, which, according to their data, reduces pain after surgery by reducing microbial contamination of wounds, improving their healing time.

Thus, the urgency of the problem of postoperative wound healing after combined surgery for combined pathology of the anal canal and rectum is quite high and contributes to the introduction of new modern surgical technologies for the treatment of this pathology, which would have minimal tissue damage, preventing pain syndrome and would promote rapid healing of postoperative wounds, leading to rapid medical and social rehabilitation of patients.

The aim of the study was to conduct a comparative morphological assessment of postoperative wound healing in patients with combined pathology of the anal canal and rectum after combined operations using modern high-frequency electrosurgical and radiosurgical technologies.

\section{Materials and methods}

In the period from January 2007 to June 2021, 689 patients with combined diseases of the anal canal and rectum were operated on in the proctology department of Public Non-Profit Enterprise "Khmelnytskyi regional hospital" under Khmelnytskyi Regional Council using the radio-wave surgery device "Surgitron" and the highfrequency electrosurgery devices "ERBE ICC 200", "EFA" and "KLS Martin". Among them 382 (55.4\%) patients were male and $307(44.6 \%)$ were female. The age of patients ranged from 18 to 76 years. All 689 patients, who were divided into 4 study groups, signed a voluntary informed consent for anesthesia and surgery, which were performed under spinal anesthesia.

Committee on Bioethics of the National Pirogov Memorial Medical University, Vinnytsya (protocol №3 From 16.03.2017) found that research, clinical trials are planned in accordance with the basic provisions of the GCP (1996), the Council of Europe Convention on Human Rights and Biomedicine (from 04.04.1997), the Helsinki Declaration of the World Medical Association on the ethical principles of scientific medical research with human participation (1964-2000) and the order of the Ministry of Health of Ukraine № 281 from 01.11.2000.

The first study group consisted of 245 patients with combined pathology of the anal canal and rectum, who were operated using a radio-wave surgery device "Surgitron". Of these, $143(58.4 \%)$ patients were male and $102(41.6 \%)$ were female. The age of patients ranged from 18 to 74 years.

The second study group consisted of 170 patients with combined pathology of the anal canal and rectum, who were operated using a high-frequency electrosurgery device "ERBE ICC 200". Of these, 105 (61.7\%) patients were male and $65(38.3 \%)$ were female. The age of patients ranged from 20 to 76 years.

The third study group consisted of 114 patients with combined pathology of the anal canal and rectum, who were operated using a high-frequency electrosurgery device "EFA". Of these, 65 (57\%) patients were male and 49 (43\%) were 
female. The age of patients ranged from 24 to 72 years.

The fourth study group consisted of 160 patients with combined pathology of the anal canal and rectum, who were operated using a high-frequency electrosurgery device "KLS Martin". Of these, 64 (40\%) patients were male and 96 patients $(60 \%)$ were female. The age of patients ranged from 19 to 65 years.

After surgery using the "Surgitron" radiosurgery device, as well as "ERBE ICC 200", "EFA" and "KLS Martin" highfrequency electrosurgery devices, 30 patients from each study group underwent morphological examination of anal canal and rectal tissues to study depth of their necrosis. Measurement of the thickness of the coagulation necrosis layer was performed using an eyepiece-micrometer scale.

The operating material was fixed in $10 \%$ neutral formalin solution. Next, the material was produced in a carousel histoprocessor type STP-120, for filling paraffin blocks used station EC-350, for cutting paraffin blocks rotary microtome series $\mathrm{HM}-340 \mathrm{E}$, for staining histological specimens - machine Robot-Stainer HMS-740 (all devices from MICROM InternationalGmbH). The drugs were stained with hematoxylin and eosin. An Axioskop 40 microscope with an Axio Cam MRc5 camera (Karl Zeiss) was used.

The dynamics of the wound process was assessed by cytological examination of smears from the surface of postoperative wounds on $3,5,7,14$ and 21 days. For this action were used cytological brushes with which the substrate was applied to slides. The material was fixed for 1 minute in the dye-fixative solution of May-Grunwald, then painted for 17 minutes with a solution of paint according to Romanovsky, washed with water and dried. Microscopy was performed with dry and immersion systems. Cytological examination was performed in 30 patients from each study group. The severity and duration of the inflammatory reaction in the wound was assessed by the number of neutrophils, the presence of dystrophic changes, the presence of macrophages, as well as the quantitative composition of the microflora. The timing of reparative signs was assessed by the appearance of cells such as histiocytes, fibroblasts, fibrocytes, as well as connective tissue fibers and squamous epithelial cells.

Statistical analysis of the obtained data was performed using IBM SPSS STATISTICS SUBSCRIPTIONAL TRIAL software. License number: L-CZAA-BHG85V. The normality check was performed using the Kolmogorov-Smirnova criteria, as amended by Lillefors. The critical level of statistical significance was 0.05 . The sample size was 120 patients. Descriptive statistics of coagulation necrosis layer depth, inpatient treatment duration and wound healing time were performed using the following indicators: $M$ - arithmetic mean, SD - standard deviation, Median, Q1-Q3 - 1st and 3 rd quartiles. The distribution of variables "Duration of inpatient treatment" and "Term of wound healing" differed from normal at the level of significance $p<0.001$ and the distribution of variables "Depth of coagulation necrosis layer" did not differ from normal at the level of significance $p=0.200$. The relationship between the variables "Coagulation necrosis layer depth" and the variables "Duration of inpatient treatment" and "Wound healing time" was analyzed using Pearson correlation coefficients ( $r$ ).

\section{Results}

The study revealed 62 variants of combined pathology of the anal canal and rectum, among which in all 4 study groups the most common were the following 10: chronic anal fissure and anal polyp - $118(17.1 \%)$; chronic anal fissure and combined hemorrhoids - $85(12.3 \%)$; combined hemorrhoids and anal fistula - 62 (8.9\%); combined hemorrhoids and anal polyp - $61(8.8 \%)$; chronic anal fissure, anal polyp and hypertrophied perianal skin tags - 41 (5.9\%); combined hemorrhoids, chronic anal fissure and anal polyp - 30 (4.3\%); anal fistula and anal polyp - 24 (3.5\%); external hemorrhoids and anal polyp - 21 (3.1\%); external hemorrhoids and anal fistula - 21 (3.1\%); external hemorrhoids and chronic anal fissure - 20 (2.9\%).

The nature of the performed surgical interventions depended on the variant of combined pathology of the anal canal and rectum. The following types of combined surgical operations were performed on patients: anal fissure excision and polypectomy - 118 (17.1\%); hemorrhoidectomy and excision of the anal fissure - 85 (12.3\%); hemorrhoidectomy and excision of the anal fistula - 62 (8.9 $\%)$; hemorrhoidectomy and polypectomy - 61 (8.8\%); excision of the anal fissure, polypectomy and electroexcision of hypertrophied perianal skin label - 41 (5.9\%); hemorrhoidectomy, anal fissure excision and polypectomy - 30 (4.3\%); hemorrhoidectomy and polypectomy - 24 (3.5 \%); hemorrhoidectomy and polypectomy - 21 (3.1\%); hemorrhoidectomy and excision of the anal fistula - 21 (3.1\%); hemorrhoidectomy and excision of the anal fissure - $20(2.9 \%)$ patients.

During the morphological study it was found that the use of radiosurgery device "Surgitron" in patients of the first study group contributed to the preservation of tissue structure with the formation of the thinnest layer of coagulation necrosis among all study groups, the average depth of which was $0.189 \pm 0.085 \mathrm{~mm}$. When using the highfrequency electrosurgical device "KLS Martin" in patients of the fourth study group, there is also preservation of tissue structure with the formation of a thin layer of coagulation necrosis along the incision edge, which is slightly deeper than in the first group with thickness $0.194 \pm 0.090 \mathrm{~mm}$. After using of high-frequency electrosurgery device "EFA" in patients of the third study group formed a deeper layer of coagulation necrosis than in the first and fourth groups, the average thickness of which was $0.208 \pm 0.097 \mathrm{~mm}$. The use of high-frequency electrosurgical device "ERBE ICC $200 "$ in patients of the second study group was accompanied by the formation of the deepest layer of coagulation necrosis among all groups, the average thickness of which was $0.302 \pm 0.107 \mathrm{~mm}$.

Comparative characteristics of the depth of coagulation 
Table 1. Comparative characteristics of using of modern radiosurgical and high-frequency electrosurgical technologies in the treatment of combined diseases of the anal canal and rectum.

\begin{tabular}{|c|c|c|c|c|c|c|c|}
\hline \multirow{2}{*}{ Group } & \multirow{2}{*}{$\mathrm{N}$} & \multicolumn{2}{|c|}{$\begin{array}{c}\text { Depth of } \\
\text { coagulation } \\
\text { necrosis layer (mm) }\end{array}$} & \multicolumn{2}{c|}{$\begin{array}{c}\text { Inpatient } \\
\text { treatment } \\
\text { duration (days) }\end{array}$} & \multicolumn{2}{c|}{$\begin{array}{c}\text { Wound } \\
\text { healing time } \\
\text { (days) }\end{array}$} \\
\cline { 3 - 9 } & & $\mathrm{M}$ & $\mathrm{SD}$ & $\mathrm{Me}$ & $\mathrm{Q} 1-\mathrm{Q} 3$ & $\mathrm{Me}$ & $\mathrm{Q} 1-\mathrm{Q} 3$ \\
\hline EFA & 30 & 0.208 & 0.097 & 5 & $4-5$ & 17 & $16-17$ \\
\hline $\begin{array}{c}\text { ERBE } \\
\text { ICC 200 }\end{array}$ & 30 & 0.302 & 0.107 & 6 & $5-7$ & 19 & $18-19$ \\
\hline $\begin{array}{c}\text { KLS } \\
\text { Martin }\end{array}$ & 30 & 0.194 & 0.090 & 4 & $3-5$ & 15 & $15-15$ \\
\hline Surgitron & 30 & 0.189 & 0.085 & 4 & $3-4$ & 15 & $14-15$ \\
\hline $\begin{array}{c}\text { General } \\
\text { sample }\end{array}$ & 120 & 0.223 & 0.104 & 5 & $4-6$ & 16 & $15-18$ \\
\hline
\end{tabular}

Note: $\mathrm{N}$ - sample volume, M - arithmetic mean, SD - standard deviation, Me - median, Q1-Q3 - 1st and 3rd quartiles.

necrosis layer, inpatient treatment duration and wound healing time with using of radiosurgery device "Surgitron", high-frequency electrosurgery devices "ERBE ICC 200", "EFA" and "KLS Martin" in surgical treatment of patients with combined diseases of anal canal and rectum are given in (Table 1).

During the correlation analysis between the variables "Duration of inpatient treatment" and "Depth of coagulation necrosis layer" it was found that the correlation between them is direct (with increasing one variable increases and the second), which is reflected in (Fig. 1). The mean force correlation, Pearson's correlation coefficient $r=0.485$ (95\% Cl: $0.440-0,680)$, is statistically significantly different from zero $(p<0.001)$.

During the correlation analysis between the variables "Duration of wound healing" and "Depth of coagulation

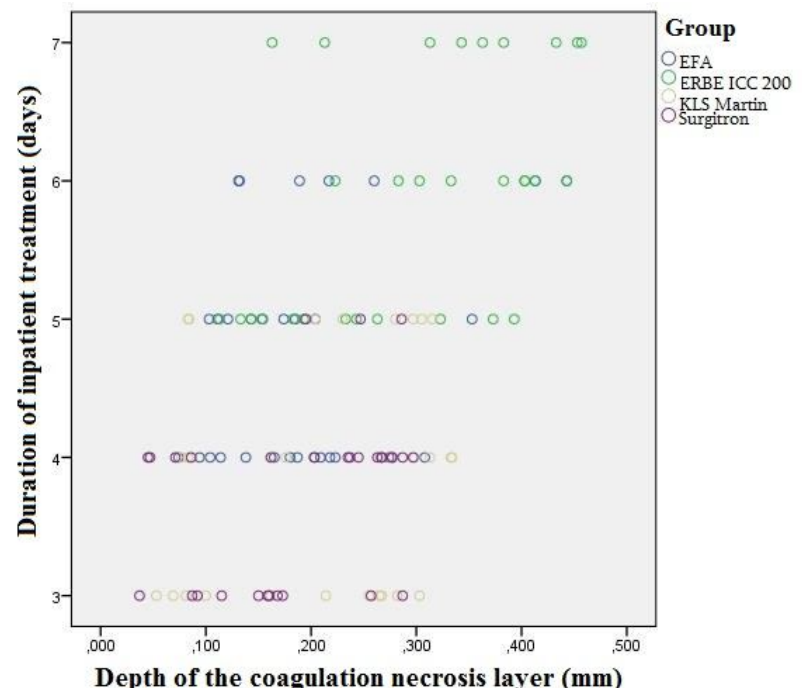

Fig. 1. Skaterograms for the entire sample in 120 patients. The color of the dot corresponds to the device used. The line diagrams show a direct linear correlation between the depth of the coagulation necrosis layer and the duration of inpatient treatment.

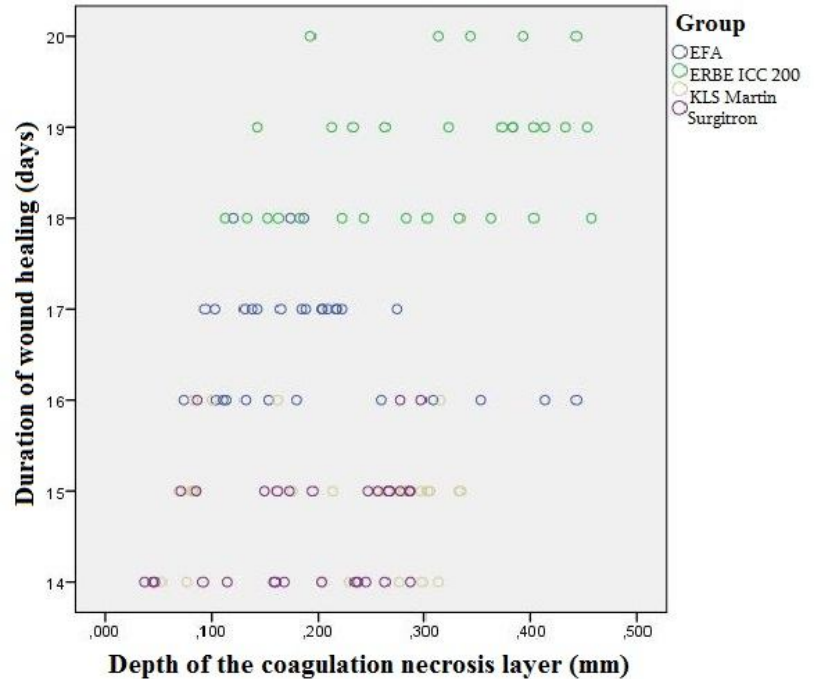

Fig. 2. Skaterograms for the entire sample in 120 patients. The color of the dot corresponds to the device used. The line diagrams show a direct linear correlation between the depth of the coagulation necrosis layer and the duration of wound healing.

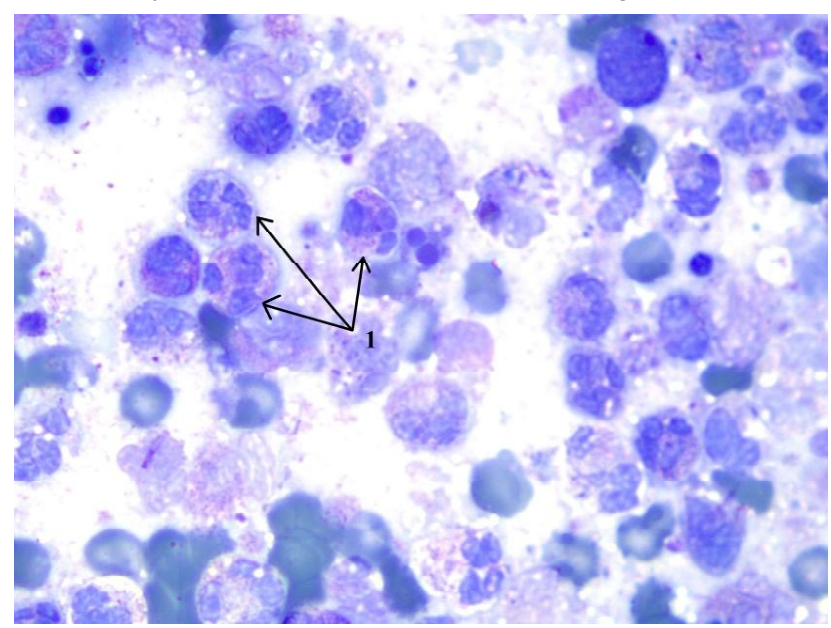

Fig. 3. Cytogram of smears from the wound surface for 3 days after surgery using the device "ERBE ICC 200". 1 - a large number of segmental neutrophils, the phenomenon of incomplete phagocytosis. Coloring by Romanovsky. x1000.

necrosis layer" it was found that the correlation between them is also direct (with increasing one variable increases and the second), which is reflected in (Fig. 2). The mean force correlation, Pearson's correlation coefficient $r=0.376$ (95\% Cl: $0.227-0.620)$, is statistically significantly different from zero $(p<0.001)$.

On the 3rd day after surgery, cytological examination of smears from the surface of postoperative wounds showed an inflammatory reaction of neutrophilic nature, which was more pronounced in the study groups, which used for surgical treatment of high-frequency electrosurgery "ERBE ICC 200" and "EFA" than in the study groups using "KLS Martin" high-frequency electrosurgery and "Surgitron" radiosurgery (Fig. 3-5).

During the analysis of smears from postoperative 


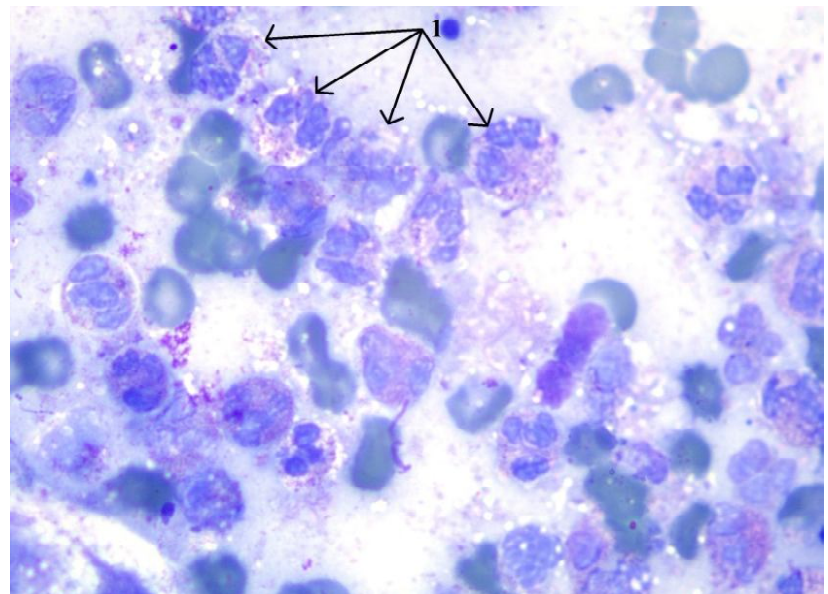

Fig. 4. Cytogram of smears from the wound surface for 3 days after surgery using the device "EFA". 1 - a large number of elements of neutrophilic inflammation, the phenomenon of incomplete phagocytosis. Coloring by Romanovsky. $\times 1000$.

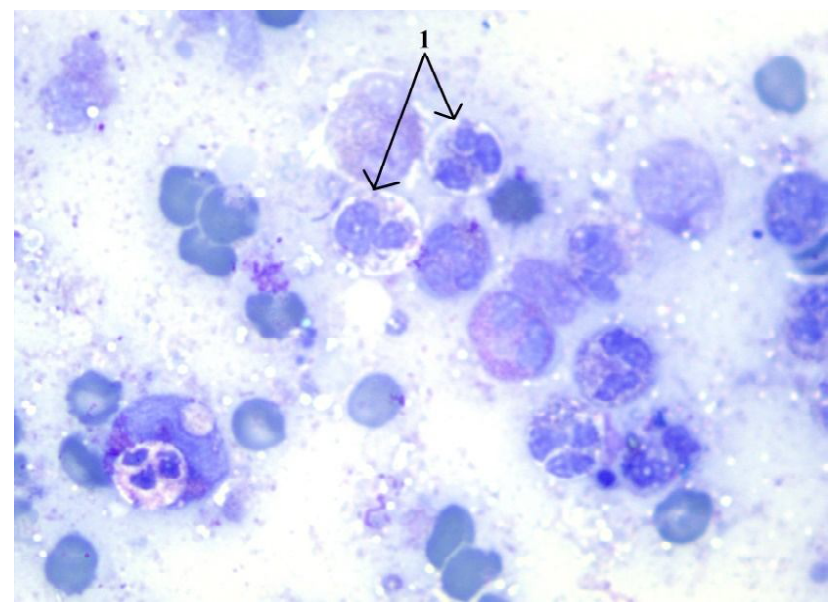

Fig. 5. Cytogram of smears from the wound surface for 3 days after surgery using the device "Surgitron". 1 - the presence of segmental neutrophils in smaller numbers (compared to the groups using the devices "ERBE ICC 200" and "EFA"), the phenomenon of incomplete phagocytosis. Coloring by Romanovsky. Coll. x1000.

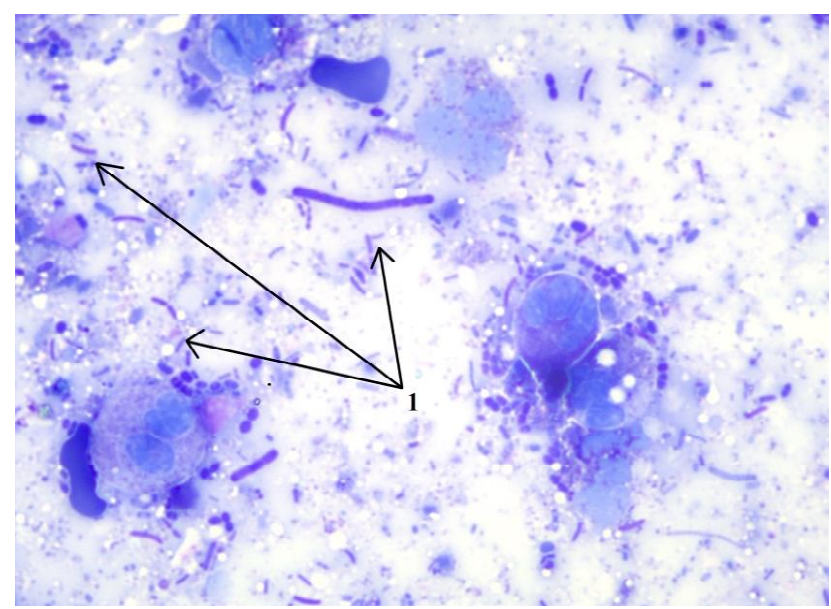

Fig. 6. Cytogram of smears from the wound surface for 5 days after surgery using the device "ERBE ICC 200". 1 - the presence of bacterial accumulations. Coloring by Romanovsky. x1000.

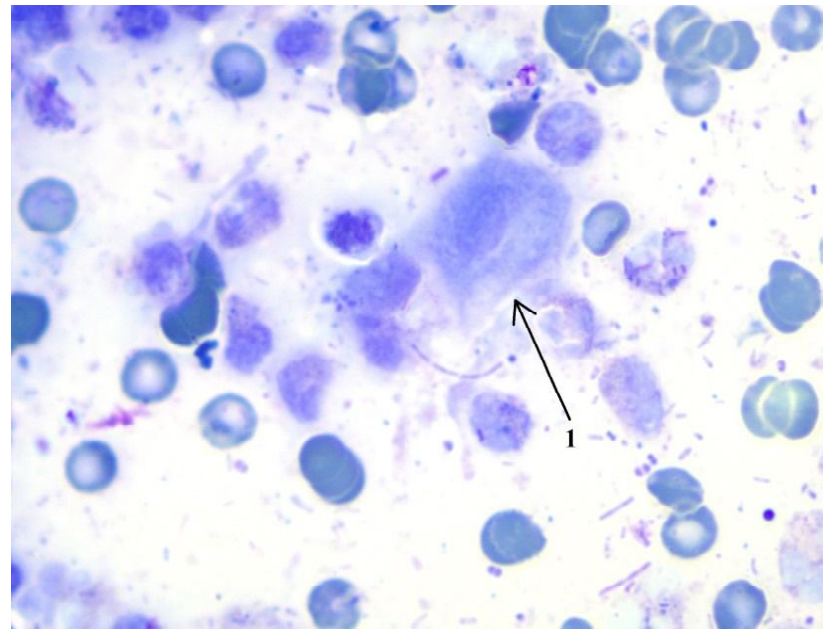

Fig. 7. Cytogram of smears from the wound surface for 5 days after surgery using the device "Surgitron". 1 - proliferation of mononuclear histiocytes. Coloring by Romanovsky. x1000.

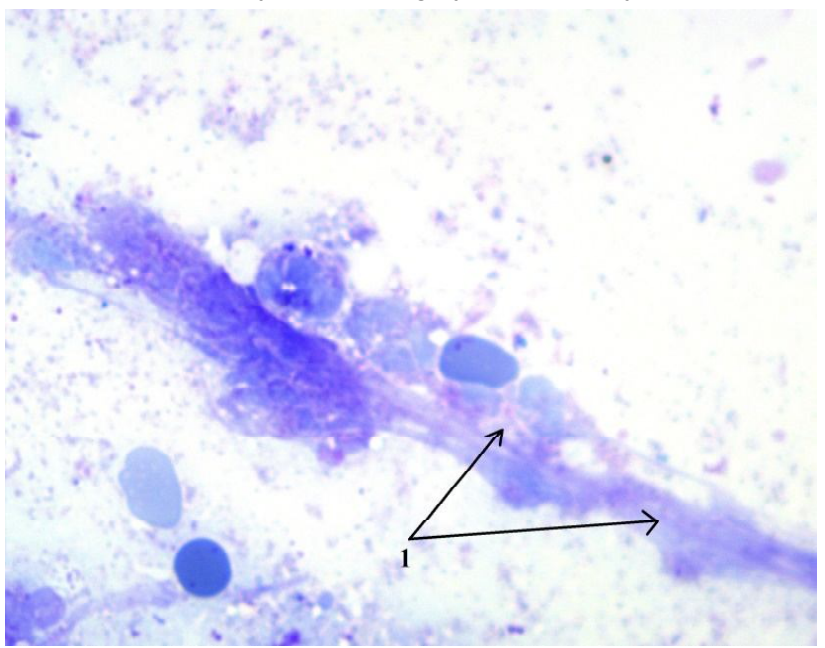

Fig. 8. Cytogram of smears from the wound surface on the 7th day after surgery using the device "KLS Martin". 1 - loose connective tissue fibers. Coloring by Romanovsky. x1000.

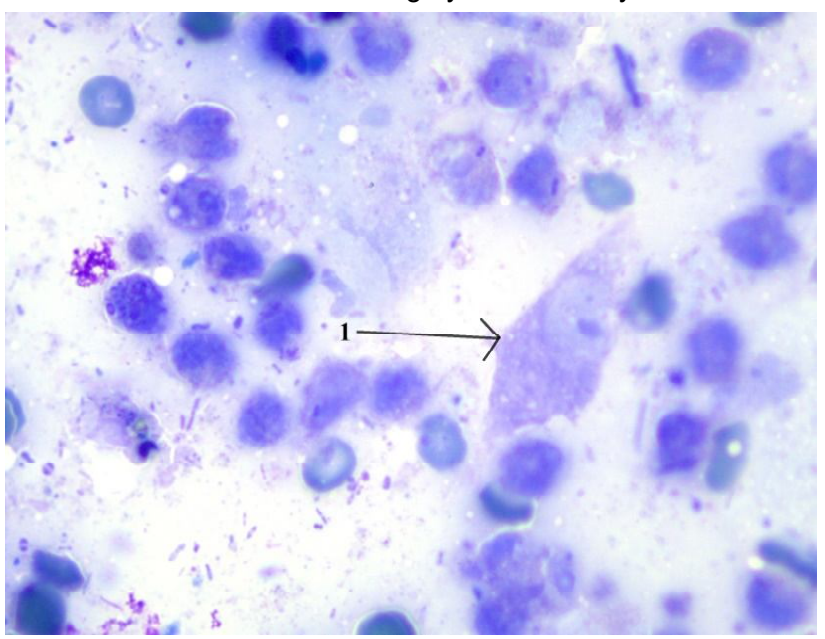

Fig. 9. Cytogram of smears from the wound surface on the 14th day after surgery using the device "KLS Martin". 1 - fibroblast. Coloring by Romanovsky. x1000. 


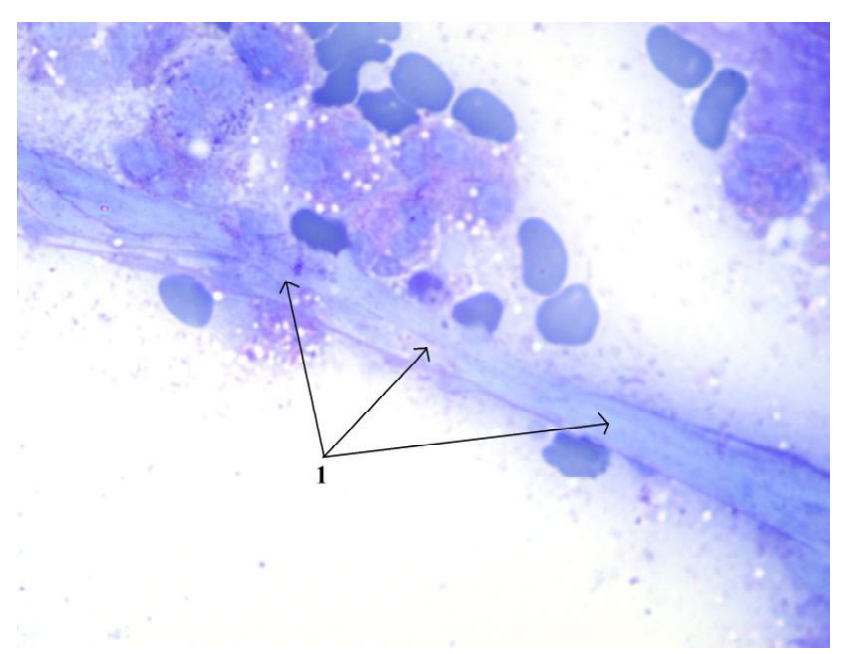

Fig. 10. Cytogram of smears from the wound surface on the 14th day after surgery using the device "Surgitron". 1 - connective tissue fibers. Coloring by Romanovsky. x1000.

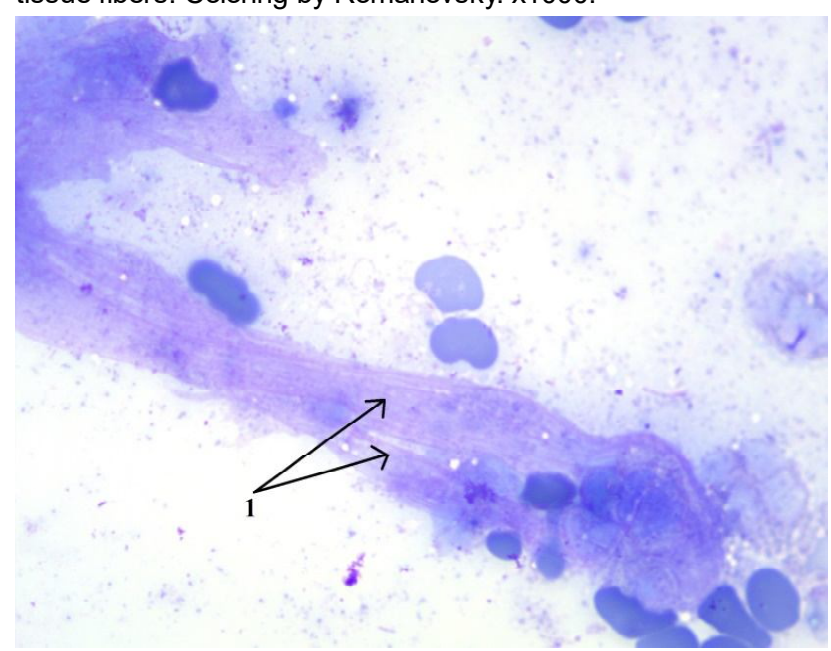

Fig. 11. Cytogram of smears from the wound surface on the 14th day after surgery using the device "KLS Martin". 1 - connective tissue fibers. Coloring by Romanovsky. x1000.

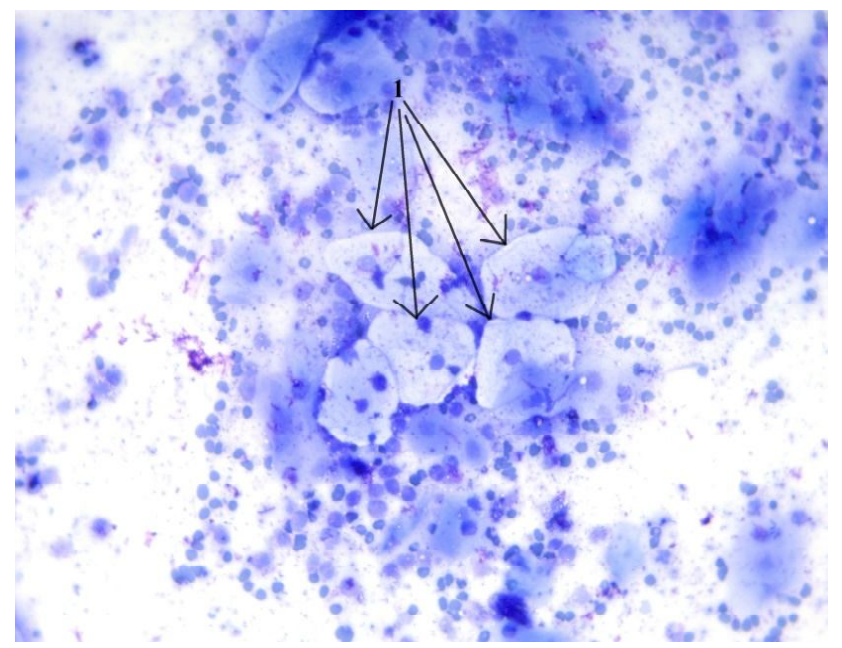

Fig. 12. Cytogram of smears from the wound surface for 21 days after surgery using the device "KLS Martin". 1 - cells of mature multilayered squamous epithelium. Coloring by Romanovsky. x400.

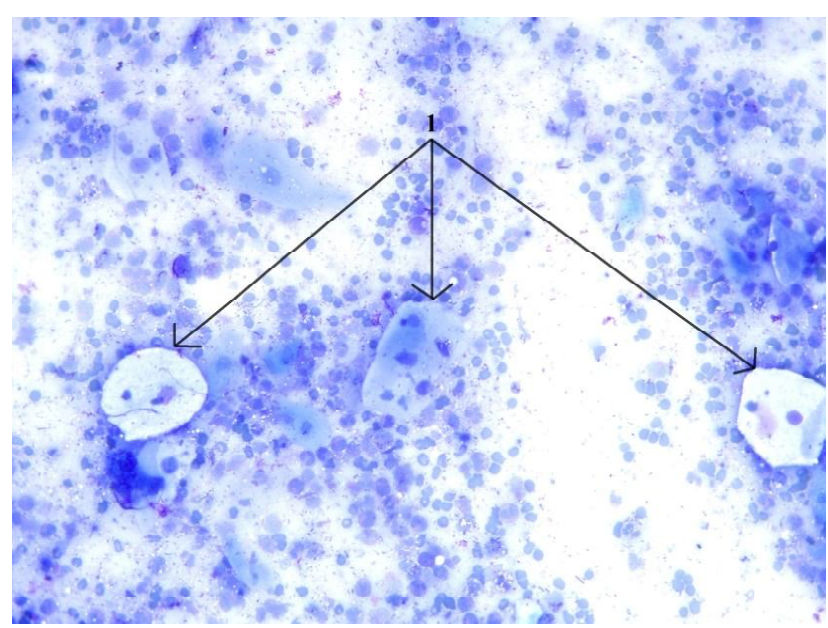

Fig. 13. Cytogram of smears from the wound surface for 21 days after surgery using the device "Surgitron". 1 - cells of mature multilayered squamous epithelium. Coloring by Romanovsky. x400.

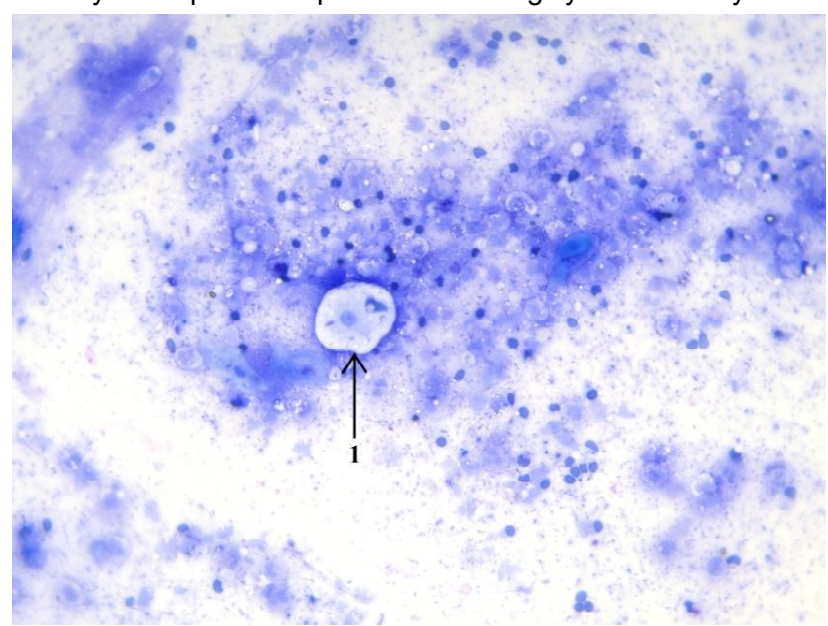

Fig. 14. Cytogram of smears from the wound surface for 21 days after surgery using the device "ERBE ICC 200". 1 - cells of mature multilayered squamous epithelium. Coloring by Romanovsky. x400.

wounds on the 5th day in patients of the 1st and 4th study groups, which used devices of high-frequency electrosurgery "KLS Martin" and radio-wave surgery "Surgitron" no pronounced inflammatory infiltration was observed, while in the 2 nd and the 3rd group of highfrequency electrosurgery devices "ERBE ICC 200" and "EFA" in half of the cases the presence of a significant number of segmental neutrophils and bacterial accumulations was preserved, which caused slower wound healing processes (Fig. 6).

In the 1st and 4th groups of patients who underwent surgery using high-frequency electrosurgery devices "KLS Martin" and radiowave surgery "Surgitron" on the 5th day after surgery, the appearance of mononuclear histiocytes (Fig. 7), and on the 7th day - loose connective tissue fibers (Fig. 8), which indicates the appearance of granulation tissue, which is a sign of reparative changes. In the 2 nd and 3rd groups of patients operated with high-frequency electrosurgery devices "ERBE ICC 200" and "EFA", 
histiocytes were not observed in smears on the 5th day after surgery and connective tissue fibers were found in isolated cases on the 7th day.

On the 14th day of the postoperative period all patients of the 1st and 4th groups with using of high-frequency electrosurgery "KLS Martin" and radio-wave surgery "Surgitron" appear immature connective tissue elements fibroblasts with large nuclei and cytoplasmic processes (Fig. 9). Also, in all preparations of patients of these groups on the 14th day there were a number of connective tissue fibers, which are actually synthesized by fibroblasts (Fig. $10,11)$. In patients of the 2 nd and 3rd groups with the use of high-frequency electrosurgery devices "ERBE ICC 200" and "EFA" on the 14th day of the postoperative period fibroblasts appeared only in isolated cases respectively and connective tissue fibers were found in a much smaller number of drugs.

On the 21st day after surgery epithelial cells with small nuclei and a significant amount of cytoplasm were found in the smears of most patients of the 1st and 4th groups using "KLS Martin" high-frequency electrosurgery and "Surgitron" radiosurgery devices, which was a sign of epithelialization processes (Fig. 12, 13). In patients operated with high-frequency electrosurgery devices "ERBE ICC 200" and "EFA" cells of mature squamous epithelium were found in a small number of cases, often in the form of single cells (Fig. 14).

\section{Discussion}

The use of "Surgitron" radio-frequency surgery and "KLS Martin" high-frequency electrosurgery devices for the treatment of patients with combined pathology of the anal canal and rectum was accompanied by the formation of the thinnest layers of coagulation necrosis in tissues with deepness of $0.189 \pm 0.085 \mathrm{~mm}$ and $0.194 \pm 0.090 \mathrm{~mm}$ respectively, resulting the patients of the first and fourth study groups had the shortest duration of inpatient treatment, which was 3-5 days and the average time of wound healing, which was 14-15 days. Patients in these study groups had the lowest inflammatory neutrophil reaction in postoperative wounds on day 3 , which rapidly disappeared by day 5, on days 7-14 they had active reparative processes with the appearance of fibroblasts and connective tissue fibers, and on 21 day of squamous epithelial cells, which indicated the processes of active epithelialization of wounds.

The effect on the tissues of high-frequency electrosurgery devices "EFA" and "ERBE ICC 200" was deeper than in the above groups, forming a layer of coagulation tissue necrosis with a depth of $0.208 \pm 0.097$ $\mathrm{mm}$ and $0.302 \pm 0.107 \mathrm{~mm}$, respectively, which was accompanied by patients of the third and second study groups with longer terms of inpatient treatment, which amounted to 5-7 days and increasing the time of wound healing, which amounted to 16-19 days. Patients in the 2nd and 3rd study groups showed a more pronounced inflammatory neutrophilic reaction in postoperative wounds on the 3rd day, which did not disappear until the 5th day and in half of the cases the presence of a significant number of segmental neutrophils and bacterial accumulations persisted, which led to slower wound healing processes. On days 7-14 they had weak reparative processes with the appearance of single fibroblasts and a small number of connective tissue fibers and on the 21 st day single squamous epithelial cells, which indicated slow processes of wound epithelization.

The obtained results indicate that the use of the above modern radiosurgical and high-frequency electrosurgical technologies is accompanied by a much smaller depth of coagulation necrosis than the use of devices "Liga Sure", "Ultra Cision", the depth of which on tissues according to some authors is from $1.5 \mathrm{~mm}$ to $2 \mathrm{~mm}[10,16]$, which causes the formation of a delicate elastic scar, preventing the occurrence of scar strictures of the anal canal and improves the rehabilitation of patients in the postoperative period.

Application of radio-wave surgery device "Surgitron" and high-frequency electrosurgery devices "ERBE ICC 200", "EFA" and "KLS Martin" due to the minimal and insignificant depth of coagulation tissue necrosis significantly reduces the inflammatory reaction in postoperative anal canal wounds, which disappears on 3-5 day, helping to reduce the time of their healing, while according to some authors, inflammatory changes in the wounds of the anal canal can last up to $14-15$ days [1].

\section{Conclusions}

1. Using of radio-wave surgery device "Surgitron" and high-frequency electrosurgery device "KLS Martin" during combined operations in patients with combined anal and rectal pathology is accompanied by the least damaging effect on tissues, contributing to the formation of a thin layer of coagulation necrosis with deepness of $0.189 \pm 0.085 \mathrm{~mm}$ and $0.194 \pm 0.090 \mathrm{~mm}$ respectively, reducing the duration of inpatient treatment of patients to 3-5 days and the average time of wound healing to 14-15 days.

2. Application of high-frequency electrosurgical devices "EFA" and "ERBE ICC 200" during combined operations in patients with combined pathology of the anal canal and rectum is accompanied by a slightly greater damaging effect on tissues, contributing to the formation of a deeper layer of coagulation necrosis with a depth of $0.208 \pm 0.097$ $\mathrm{mm}$ and $0.302 \pm 0.107 \mathrm{~mm}$ respectively, increasing the duration of inpatient treatment of patients to 5-7 days and the average time of wound healing to 16-19 days.

3. Application of radio-wave surgery device "Surgitron" and high-frequency electrosurgery devices "ERBE ICC 200", "EFA" and "KLS Martin" due to the minimal and insignificant depth of coagulation necrosis of tissues promotes their active epithelialization, preventing the occurrence of scar strictures of the anal canal and improves the rehabilitation of patients in the postoperative period. 


\section{References}

[1] Bhatti, M. I., Sajid, M. S., \& Baig, M. K. (2016). Milligan-Morgan (Open) Versus Ferguson Haemorrhoidectomy (Closed): A Systematic Review and Meta-Analysis of Published Randomized, Controlled Trials. World J. Surg., 40(6), 15091519. doi: 10.1007/s00268-016-3419-z

[2] Borota, A. V., Kuhto, A. P., Bazijan-Kuhto, N. K., \& Borota, A. A. (2018). Сравнительный анализ хирургического лечения сочетанной неопухолевой патологии анального канала и прямой кишки [Comparative analysis of surgical treatment of combined non-tumor anal canal and rectal pathology]. Новообразование - Neoplasm, 10(1), 18-21. doi: 10.26435/ neoplasm.v10i1.242

[3] Brusciano, L., Gambardella, C., Terracciano, G., Gualtieri, G., Schiano di Visconte, M., Tolone, S. ... Docimo, L. (2020). Postoperative discomfort and pain in the management of hemorrhoidal disease: laser hemorrhoidoplasty, a minimal invasive treatment of symptomatic hemorrhoids. Updates Surg., 72(3), 851-857. doi: 10.1007/s13304-019-00694-5

[4] Du, T., Quan, S., Dong, T., \& Meng, Q. (2019). Comparison of surgical procedures implemented in recent years for patients with grade III and IV hemorrhoids: a network meta-analysis. Int. J. Colorectal. Dis., 34(6), 1001-1012. doi: 10.1007/s00384019-03288-0

[5] Eshghi, F., Hosseinimehr, S. J., Rahmani, N., Khademloo, M., Norozi, M. S., \& Hojati, O. (2010). Effects of Aloe vera cream on posthemorrhoidectomy pain and wound healing: results of a randomized, blind, placebo-control study. J. Altern. Complement. Med., 16(6), 647-650. doi: 10.1089/ acm.2009.0428

[6] Faes, S., Pratsinis, M., Hasler-Gehrer, S., Keerl, A., \& Nocito, A. (2019). Short- and long-term outcomes of laser haemorrhoidoplasty for grade II-III haemorrhoidal disease. Colorectal Dis., 21(6), 689-696. doi: 10.1111/codi.14572

[7] Giamundo, P., De Angelis, M., \& Mereu, A. (2020). Hemorrhoid laser procedure with suture-pexy (HeLPexx): a novel effective procedure to treat hemorrhoidal disease. Tech. Coloproctol., 24(2), 199-205. doi: 10.1007/s10151-020-02152-6

[8] Kim, J. H., Kim, D. H., Baik, S. Y., \& Lee, Y. P. (2020). Pain control and early wound healing effect using sitz bath with ozonised water after haemorrhoidectomy. J. Wound Care., 29(5), 289294. doi: 10.12968/jowc.2020.29.5.289

[9] Kuz'minov, A. M., Frolov, S. A., Vyshegorodtsev, D. V., Korolik, V. Yu., Tuktagulov, N. V., Sukhina, M. A., \& Vorob'yeva, I. V. (2020). Первый опыт применения низкотемпературной аргоновой плазмы в лечении ран после открытой геморроидэктомии [The first experience of low-temperature argon plasma application in the treatment of wounds after open hemorrhoidectomy]. Новости хирургии - Surgery news, 28(5), 543-549. doi: 10.18484/2305-0047.2020.4.543

[10] Lim, D. R., Cho, D. H., Lee, J. H., \& Moon, J. H. (2016). Comparison of a Hemorrhoidectomy With Ultrasonic Scalpel Versus a Conventional Hemorrhoidectomy. Ann. Coloproctol., 32(3), 111-116. doi: 10.3393/ac.2016.32.3.111

[11] Milito, G., Lisi, G., Aronadio, E., Campanelli, M., Venditti, D., Grande, S., \& Grande, M. (2017). Ligasure TM hemorrhoidectomy: how we do. Minerva Gastroenterol. Dietol., 63(1), 44-49. doi: 10.23736/S1121-421X.16.02343-6

[12] Pares, D., \& Abcarian, H. (2018). Management of Common Benign Anorectal Disease: What All Physicians Need to Know. Am. J. Med., 131(7), 745-751. doi: 10.1016/ j.amjmed.2018.01.050

[13] Poskus, T., Danys, D., Makunaite, G., Mainelis, A., Mikalauskas, S., Poskus, E., ... \& Strupas, K. (2020). Results of the doubleblind randomized controlled trial comparing laser hemorrhoidoplasty with sutured mucopexy and excisional hemorrhoidectomy. Int. J. Colorectal. Dis., 35(3), 481-490. doi: 10.1007/s00384-019-03460-6

[14] Rodríguez-Wong, U., Rodríguez-Medina, U., \& Medina-Murillo, G. R. (2019). Randomized clinical trial with topical diltiazem for post-hemorrhoidectomy wound healing. Rev. Gastroenterol. Mex., 84(1), 119-122. doi: 10.1016/j.rgmx.2018.10.001

[15] Shelygin, Yu. A., Podmarenkova, L. F., Blagodarnyy, L. A., Khmylov, L. M., Maksimova, L. V., \& Zharkov, Ye. E. (2006). Патогенез болевого синдрома после геморроидэктомии [Pathogenesis of pain syndrome after hemorrhoidectomy]. Колопроктология - Coloproctology, 3(17), 3-11.

[16] Sottayeva, V. Kh., Frolov, S. A., Blagodarnyy, L. A., Maksimova, L. V., \& Khmylov, L. M. (2007). Характер течения раневого процесса после аппаратной геморроидэктомии [The nature of the wound process after hardware hemorrhoidectomy]. Колопроктология - Coloproctology, 4(22), 9-14.

[17] Talha, A., Bessa, S., \& Abdel Wahab, M. (2017). Ligasure, Harmonic Scalpel versus conventional diathermy in excisional haemorrhoidectomy: a randomized controlled trial. ANZ J Surg, 87(4), 252-256. doi: 10.1111/ans. 12838

[18] Vejdan, A. K., Khosravi, M., Amirian, Z., Daneshmand, M., Babak, B., Samira, K. ... Razie, K. (2020). Evaluation of the efficacy of topical sucralfate on healing haemorrhoidectomy incision wounds and reducing pain severity: A randomised clinical trial. Int. Wound J., 17(4), 1047-1051. doi: 10.1111/ iwj.13369

\section{МОРФОЛОГІЧНА ОЦІНКА ЗАГОЄННЯ РАН АНАЛЬНОГО КАНАЛУ ПІСЛЯ КОМБННОВАНИХ ОПЕРАЦІЙ 3 ПРИВОДУ ПОЄДНАНОÏ АНОРЕКТАЛЬНОЇ ПАТОЛОГІЇ}

\section{Балицький В.В.}

Актуальність проблеми загоєння післяопераційних ран після комбінованих операцій з приводу поєднаної аноректальної патології є досить високою і сприяє впровадженню в практику колопроктологів нових сучасних хірургічних технологій для лікування цієї патології. Метою дослідження було проведення порівняльної морфологічної оцінки загоєння післяопераційних ран у пацієнтів з поєднаною патологією анального каналу і прямої кишки після комбінованих операцій з використанням сучасних високочастотних електрохірургічних та радіохірургічних технологій. Проаналізовані результати хірургічного лікування 689 пацієнтів з поєднаною патологією анального каналу і прямої кишки з використанням апаратів високочастотної електрохірургії та радіохвильової хірургії з морфологічною оцінкою загоєння ран на 3, 5, 7, 14, 21 добу післяопераційного періоду, які були розподілені на 4 досліджувані групи. Застосування апаратів "Surgitron" ma "KLS Martin" для лікування хворих на поєднану патологію анального каналу і прямої кишки супроводжувалось утворенням найтонших шарів коагуляційного

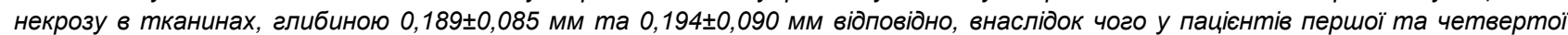
досліджуваних груп були найменшими терміни стаціонарного лікування, котрі становили 3-5 діб та середні терміни загоєння ран, котрі становили 14-15 діб. У пацієнтів цих досліджуваних груп відмічалась найменша запальна нейтрофільна реакція 
в післяопераційних ранах на 3 добу, яка швидко зникала до 5 доби, на 7-14 добу у них відмічались активні репаративні процеси з появою фібробластів та волокон сполучної тканини, а на 21 добу клітин плоского епітелію, що свідчило про активну епітелізацію рани. Вплив на тканини апаратів "ЭФА" та "ERBE ICC 200" був глибшим, ніж у вищенаведених групах, утворюючи

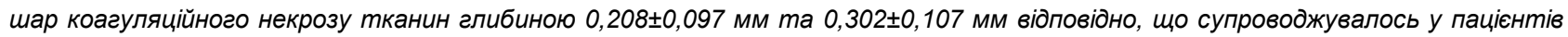
третьої та другої досліджуваних груп більшими термінами стаціонарного лікування, котрі становили 5-7 діб та збільшенням термінів загоєння ран, котрі становили 16-19 діб. На третю добу у пацієнтів 2 та 3 досліджуваних груп відмічалась більш виражена запальна нейтрофрільна реакція в післяопераційних ранах, котра не зникала до 5 доби і у половині випадків зберігались як наявність значної кількості сегментоядерних нейтрофрілів, так і скупчень бактерій. На 7-14 добу у них відмічались слабкі репаративні процеси з появою поодиноких фрібробластів та невеликої кількості волокон сполучної тканини, а лише на 21 добу поодинокі клітини плоского епітелію, що свідчило про повільну епітелізацію рани. Застосування апарату радіохвильової хірургії та апаратів високочастотної електрохірургії сприяє активній епітелізації тканин, запобігаючи виникненню рубцевих стриктур анального каналу, і покращує терміни реабілітації пацієнтів у післяопераційному періоді.

Ключові слова: морфологічна оцінка, поєднана аноректальна патологія, комбіновані операції, апарати високочастотної електрохірургії, апарат радіохвильової хірургії, загоєння ран. 